Grzegorz Maziarczyk, The John Paul II Catholic University of Lublin, Poland Wojciech Drąg, University of Wroclaw, Poland

DOI: $10.17951 / \mathrm{Ismll} .2020 .44 .2 .1-2$

\title{
Narrative Fiction and Other Media: An Introduction
}

The new millennium has seen a resurgence of literary narratives which combine a variety of semiotic modes, such as text, image, font and layout, speech, sound and video. Some of those works situate themselves in the tradition of postmodernist experimentation (represented by such authors as B. S. Johnson, William H. Gass and Raymond Federman), while others aspire to break out of the avant-garde niche and reach a wider audience. As demonstrated by the examples of Douglas Coupland's Generation X (1991), Mark Z. Danielewski's House of Leaves (2000) and Jonathan Safran Foer's Extremely Loud and Incredibly Close (2005), multimodal novels are capable of gaining the status of bestsellers. They have succeeded in appealing to a broader audience because most readers are used to the multimedia environment of print, film, computer etc. By drawing on readers' experiences with other media, the form of contemporary fiction is becoming increasingly hybrid. Over the last two decades, literature has productively engaged with the computer (digital/ electronic literature), videogames (interactive fiction), touchscreen devices (Reif Larsen's Entrances and Exits, 2016), photography (works by W.G. Sebald and Steve Tomasula), painting (Tom Phillips's A Humument, 1970-2016) and sculpture (Safran Foer's Tree of Codes, 2010). A synthesis of text, image, sound and video, Tomasula's TOC: A New-Media Novel (2009) may be a harbinger of how fiction will evolve in the decades to come.

This special section aims to contribute to a growing body of academic criticism devoted to generic hybridity and multimodal literature. Among the most important monographs about formally unconventional fiction published over the last decade one can mention The Routledge Companion to Experimental Literature (2012) edited by Joe Bray, Alison Gibbons and Brian McHale, Gibbons's Multimodality,

Grzegorz Maziarczyk, Katedra Literatury i Kultury Amerykańskiej, Katolicki Uniwersytet Lubelski Jana Pawła II, Al. Racławickie 14, 20-950 Lublin, grzegorz.maziarczyk@kul.lublin.pl,

https://orcid.org/0000-0002-6859-152

Wojciech Drąg, Instytut Filologii Angielskiej, Uniwersytet Wrocławski, Plac Uniwersytecki 1, 50-137 Wrocław, wojciech.drag@uwr.edu.pl, https://orcid.org/0000-0002-9089-2465 
Cognition, and Experimental Literature (2012), Grzegorz Maziarczyk's The Novel As Book: Textual Materiality in Contemporary Fiction in English (2013), New Literary Hybrids in the Age of Multimedia Expression: Crossing Borders, Crossing Genres (2014) edited by Marcel Cornis-Pope, Simon Barton's Visual Devices in Contemporary Prose Fiction: Gaps, Gestures, Images (2015), Katarzyna Bazarnik's Liberature: A Book-Bound Genre (2018) and The Poetics of Fragmentation in Contemporary British and American Fiction (2019) edited by Vanessa Guignery and Wojciech Drąg. Each of those studies testifies to the myriad ways in which contemporary literature challenges the notion of a literary work as a codex composed of white sheets of paper with rectangular blocks of text on either side and seeks to refashion itself in the media-saturated world by creatively mingling with other arts.

The contributions to this special section reflect a variety of theoretical and critical approaches to intermedial narrative fiction. Dominika Bugno-Narecka examines the relation between word and image in terms derived from Neobaroque studies in order to propose a dynamic model of ekphrasis as a fold. Drawing on Gérard Genette's distinction between immanence and transcendence, Jarosław Hetman discusses the ways in which innovative interart references reinvigorate contemporary novels in English. Aleksander Bednarski's contribution fills in a lacuna in intermedial studies by providing an overview of pictorial insets in recent Welsh-language fiction. In his analysis of the relationship between Gerhard Richter's photo-painting series October 18, 1977 and Don DeLillo's short story "Baader Meinhof", Tristan Ireson-Howells explores parallels between pictorial and verbal problematisation of the act of viewing. The applicability of traditional models of ekphrasis to narrative fiction evoking photography is discussed by Miriam de Paiva Vieira and Joicy Silva Ferreira in relation to Saura Baume's novel A Line Made by Walking. Katarzyna Biela expands the scope of intermedial studies by focusing on references to the newspaper as a medium in B. S. Johnson's The Unfortunates. In his reading of J. G. Ballard's The Atrocity Exhibition, Marcin Tereszewski relates its media-saturated fragmentation of the novel form to the cultural shift towards spectacular society. Subversion of genre boundaries figures equally prominently in a contribution by Dominika Ferens, who investigates the graphic novel Lissa: A Story about Medical Promise, Friendship, and Revolution as an experimental alternative to an ethnographic monograph. In his application of the findings of digital discourse studies to Nicola Barker's $H(A) P P Y$, Joe Darlington examines the political potential of innovative multimodal techniques. Finally, Wojciech Drąg's contribution goes beyond print literature in its Barthesian investigation of David Clark's digital biography 88 Constellations for Wittgenstein (to be played with the Left Hand). Taken together, the essays collected in this special section demonstrate the artistic vitality of formal intersections between narrative fiction and other media. 